\title{
College Students' Law Education Platform Based on Browser/Server and Massive Open Online Courses
}

\author{
https://doi.org/10.3991/ijet.v14i15.11153 \\ Xue Yang, Zhen Song ( $\left.{ }^{\varpi}\right)$ \\ Shijiazhuang Vocational College of Finance \& Economics, Shijiazhuang, China \\ Songsweoi@126.com
}

\begin{abstract}
It is compulsory for us to strength the students' law education in China in order to develop their overall qualities. It is also what we need to build a harmonious society. Along with the steady advancement of society, the surge of information technologies has contributed to the integration of various new teaching methods, models and platforms into the law education. This paper, based on the browser/server $(\mathrm{B} / \mathrm{S})$ architecture and the concept of Massive Open Online Courses (MOOCs), attempt s to profoundly analyze relevant situation of students' law education in universities. According to the findings, it is found that the teaching of MOOCs in China is evolving at full speed. User groups show different preferences for the disciplines since they have a great demand for vocational skills and undergraduate education. In China, there are some gaps in the law education in universities, for example, the teaching and evaluation methods look like relatively single, there is lack of pedagogical practices, teachers' pedagogies remain to be improved, and students' enthusiasm of legal education is low. The curriculum refinement and the mobile clients developed intensively constantly improve the design of the law education platform for students in universities. The study is beneficial to the construction of law education platform for students in universities in China.
\end{abstract}

Keywords-Browser/server (B/S) architecture, massive open online course (mooc), law education platform

\section{Introduction}

To develop the overall qualities of students and build a harmonious society in our country, it is required to strengthen the law education for them in universities [1]. The development of legal education system is a relatively complex, enormous and systematic project. Today, the minds of students in China are more active, which makes their individual characters more highlighted. However, they have less awareness of laws and regulations. In the new era, students' law education can no longer depend solely on traditional classroom education in universities, but requires an innovation in teaching methods, models and platforms [2].

As Internet and information technologies have sprung up, MOOCs, a new Webbased teaching technology, emerges to provide a new idea for students' law education 
in universities. With a law education platform developed for students, the gaps in current law education system can be filled [3]. Based on the $\mathrm{B} / \mathrm{S}$ architecture and the concept of MOOCs, this paper take the organic integration between the MOOC and the students' law education system as entry point, analyzes the current development of MOOCs in China and reveals the open problems students face in law education. Given the above, a law education platform based on $\mathrm{B} / \mathrm{S}$ architecture and the concept of MOOCs is proposed for students. It, as a guiding reference, makes sense in the current legal education of students in universities in China [4].

\section{$2 \quad \mathrm{~B} / \mathrm{S} \mathbf{B} / \mathrm{S}$ Architecture}

The B/S (Browser/Server) architecture gradually emerges with constant development of information technology. Under this architecture, the user interface can be implemented by the browser. The whole system is mainly divided into three layers [5], see Fig 1 for its structure. This system has one great advantage, that is, it can be operated anywhere, no need to install special software.

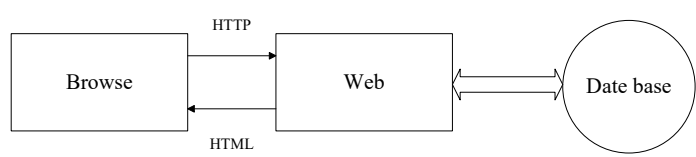

Fig. 1. B/S Architecture Based on Web

B/S application system consists of browser and server. The server has a multilayered structure where data and applications are stored; the browser's functions can be gradually expanded by downloading the applications on the server. Users can make a request to the server on the network via the browser, and the server processes it, and feeds back users' needs via the browser [6]. In this way, the server takes more work to greatly unload the client. However, there is certain gap in the $\mathrm{B} / \mathrm{S}$ architecture, for example, the Web server becomes the only client for the database, and needs to process the user's needs and data links in parallel. When there are too many users who access the server simultaneously, the server is prone to crashing [7]. In view of this problem, a new type of system can be developed based on the original $\mathrm{B} / \mathrm{S}$ architecture, as shown in Fig 2. It can effectively reduce the load on the client computer and greatly reduce the system maintenance cost.

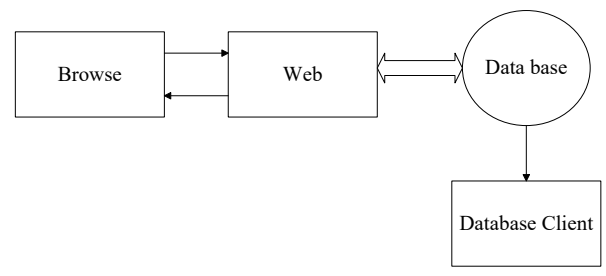

Fig. 2. New B/S Architecture 


\section{Introduction to the Development of MOOCs in China}

\subsection{Concept of MOOCs}

MOOC, the Massive Open Online Course, originally originated in the United States, has its own curriculum construction concept, that is, in the virtual network environment, the time and space limits are broken to provide learners with premium courses that have a complete teaching process and abundant learning support services. As a new type of education formation, MOOC uses the Internet technology to fully integrate open education with online education and applies it on a large scale [8].

MOOC can be integrated into the process of students' law education, which, on the one hand, can ensure that students can acquire knowledge whenever and wherever possible, and on the other hand, students can gain the latest knowledge by continuously updating teaching resources [9]. For law education, lots of knowledge and contents are objective. The purpose of students' law education is to let each of them have a full comprehension of knowledge about laws and then develop a legal thinking, and never do anything emotionally. All students can learn under the one platform, thus effectively debasing unbalance and unfairness of education development.

\subsection{Development of MOOCs in China}

By the end of 2018, more than 150 top universities around the world have launched excellent courses on the MOOC platform. Udacity, Coursera and edX are the three most representative "MOOC" platforms in the world. The MOOC education was officially introduced into China in 2012, and since its inception, it has witnessed a rapid development in just a few years. The number of MOOC users has increased from 1.8 million in 2013 to 15.03 million in 2017, as shown in Fig 3.

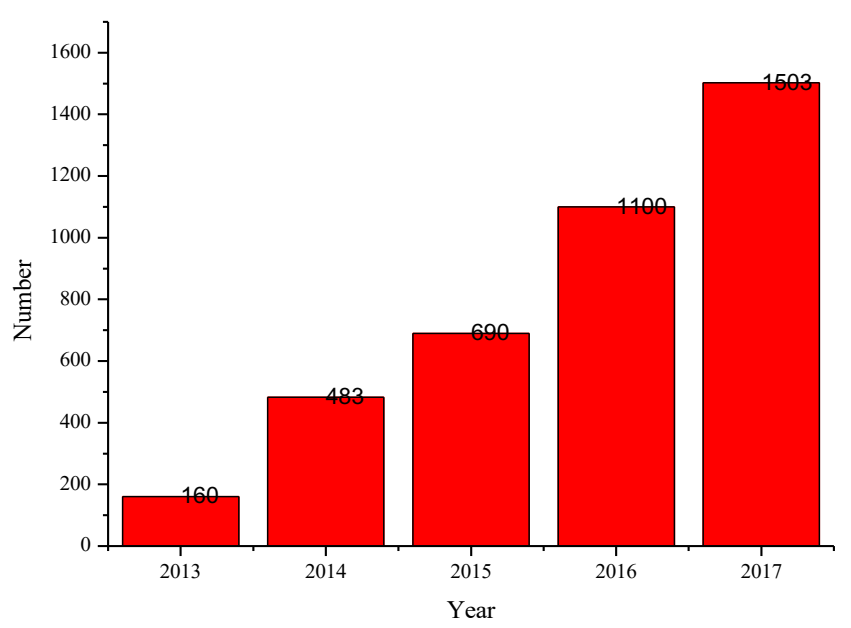

Fig. 3. The Number Map of Mu Course Users in China from 2013 to 2017 
For different user groups, there is a certain difference in the preference for the courses. In general, however, all user groups have a great demand for vocational skills and undergraduate education, accounting for $61.2 \%$ and $44.3 \%$, respectively, and the user group of students is larger than the user group of incumbents, as shown in Table 1.

Table 1. Course preferences of different user groups

\begin{tabular}{|l|c|c|c|}
\hline & User Population & Student Users & On-the-Job User \\
\hline Vocational Skills & $61.2 \%$ & $45.3 \%$ & $70.6 \%$ \\
\hline Undergraduate education & $44.3 \%$ & $67.8 \%$ & $30.4 \%$ \\
\hline Postgraduate Education & $32.4 \%$ & $35.6 \%$ & $29.8 \%$ \\
\hline Postgraduate entrance examination & $17.4 \%$ & $20.5 \%$ & $13.6 \%$ \\
\hline Study abroad & $12.8 \%$ & $17.6 \%$ & $12.3 \%$ \\
\hline Subsidiary Courses for College Students & $7.8 \%$ & $6.9 \%$ & $0.8 \%$ \\
\hline
\end{tabular}

Compared with other online education models and traditional classroom teaching methods, MOOC has better advantages, mainly reflected in some ways: there are more students participating in the learning process, the learning is not limited by time and space, and the curriculum coverage is wide, teaching programs and materials are relatively complete [10]. See Table 2 for details.

Table 2. The Difference between MOOC and Some Network Teaching Forms and Traditional Teaching Forms

\begin{tabular}{|c|c|c|c|c|}
\hline & MOOC & $\begin{array}{l}\text { Open Online } \\
\text { Courses }\end{array}$ & $\begin{array}{c}\text { Personal Tech- } \\
\text { nology Blog }\end{array}$ & $\begin{array}{c}\text { Traditional ClassRoom } \\
\text { Education }\end{array}$ \\
\hline Number of students & Unrestricted & Unrestricted & Unrestricted & subject to Limitations \\
\hline $\begin{array}{l}\text { Learning Time and } \\
\text { Space }\end{array}$ & Unrestricted & Unrestricted & Unrestricted & subject to Limitations \\
\hline $\begin{array}{l}\text { Coverage of Course } \\
\text { Content }\end{array}$ & Very broad & $\begin{array}{l}\text { Subjects Limited to } \\
\text { Network Community }\end{array}$ & Very Broad & $\begin{array}{l}\text { Limited by the Educational } \\
\text { Resources Available in } \\
\text { Schools }\end{array}$ \\
\hline Teaching Plan & Complete & No & No & Complete \\
\hline $\begin{array}{l}\text { Teaching Discussion } \\
\text { Area }\end{array}$ & Yes & Yes & Yes & No \\
\hline $\begin{array}{l}\text { Assignments and } \\
\text { Examination Assis- } \\
\text { tants }\end{array}$ & Yes & No & No & Yes \\
\hline \begin{tabular}{|l} 
Confirmation of \\
Course Completion
\end{tabular} & Certificate & No & No & Credit \\
\hline Cost & $\begin{array}{l}\text { Free Admis- } \\
\text { sion }\end{array}$ & Free Admission & Free Admission & Charge \\
\hline Course Update Notice & $\begin{array}{l}\text { Mail Notifi- } \\
\text { cation }\end{array}$ & No & No & No \\
\hline
\end{tabular}




\section{Problems in the Law Education for Students in China}

In the teaching process, laws as a very important course should be heeded and targeted for students by universities. However, judging from the current situation of law education for students in China, there are still many problems in the law education in china's universities, mainly reflected in the following areas:

\subsection{Relatively simple teaching and evaluation methods}

Today, most of the law education systems for students in universities are traditional classroom teaching models, relatively simple, because they only focus on the imparting of legal knowledge, neglect the explanation of legal doctrines and the cultivation of legal consciousness, thus directly leading this model to focusing only on the interpretation of basic theories. Law learning has a strong logic. Students will fall into great difficulties in the learning process, which also discourages them and make them lose interests in learning. For this reason, a negative impact will be applied on the teaching quality. As evaluated in China, students' law education is relatively simple because it only focuses on classroom teaching and neglects the pedagogical practices, causing students to misunderstand legal knowledge learning and fail to correctly recognize the significance of learning laws.

\subsection{Lack of pedagogical practice}

Today, the students' law education in China basically focuses on classroom teaching and knowledge transference, only educates students with basic legal knowledge, but does not tell students how to use legal knowledge to protect their legitimate rights and interests. Students cannot make full use of what they have learned in real life. In the teaching process, not only are teachers under great pressure, but students are also very labored [11].

\subsection{Low teaching level of teachers}

Teachers' teaching level will have direct concern with teaching quality. It is found from the survey that teachers in some universities in China are not adept in law education, and even some have never accepted a professional training in this discipline. In the teaching process, they only follow the textbooks, and do not talk as little as possible or not at all about legal problems unknown to them. Some teachers, even though major in this discipline, only inculcate the knowledge of textbooks in students. It is impossible for them to combine theoretical knowledge with real-life cases, so that the development of law education for students in universities is greatly spoiled to lash the improvement of teaching quality. 


\subsection{Low enthusiasm for law education}

Now, students in domestic universities lack a correct acknowledgement to law education. Many students only regard it as a course to learn, therefore, show low enthusiasm for learning it. As shown in Table 3, a survey conducted by an institution in China gives the attitude students hold towards the learning laws in universities. It is clear from relevant data that less than $15 \%$ of students take a certain interest in law education. The students' attitude towards legal knowledge absorption has a direct bearing on the quality of law education in universities.

Table 3. A data survey of college students' attitudes towards learning law

\begin{tabular}{|l|c|c|c|}
\hline Attitude & No interest & Low interest & Have interest in \\
\hline Proportion & $56.5 \%$ & $29.3 \%$ & $14.2 \%$ \\
\hline
\end{tabular}

\section{Design and Implementation of Students' Law Education Platform}

The MOOC provides high-quality and free courses for students from universities. It attributes the law education platform designed and implemented for students to teaching quality enhancement and the development of MOOCs in China. With the B/S architecture, it is possible to effectively implement the functions of course search and screening, refine the courses, and also intensify the development of the mobile client to facilitate students in learning [12].

\subsection{Refine and classify the courses}

Curriculum refinement is enabled with course weeder to bring great convenience to the students. With it, students can quickly select the courses they are interested in. Based on the B/S architecture system, the screening and setting of courses on the law education platform is more refined for students. For example, the classification of courses from difficulty and coverage, it is further rated to be introductive, intermediate and advanced in term of difficulty, and also subdivided for specific positions and skills in term of coverage, as shown in Fig 4. Students can choose the appropriate course to learn according to their own situation. 


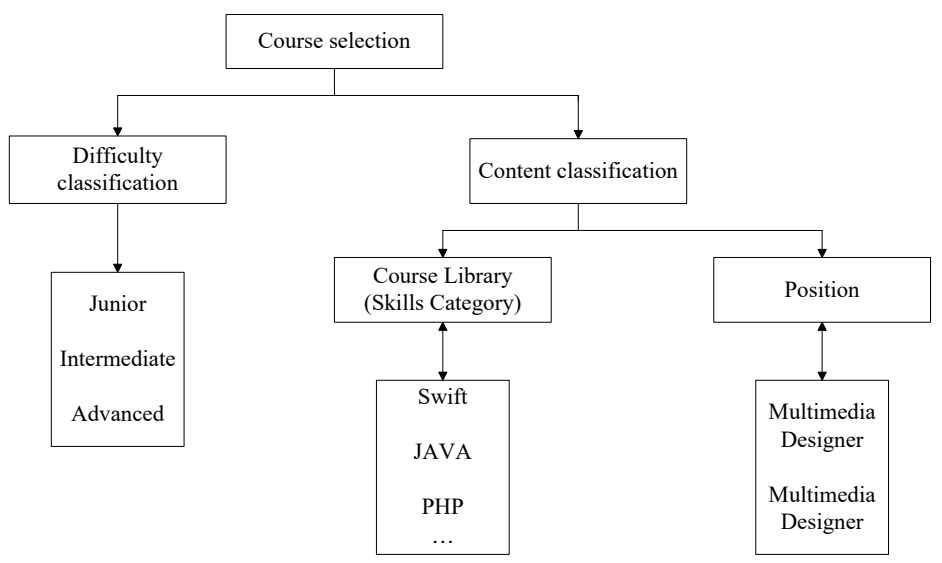

Fig. 4. Course screening system of "Mu Course Net"

\subsection{Intensify the development of mobile clients}

Based on the $\mathrm{B} / \mathrm{S}$ application system, the mobile client of the law education platform is continuously developed for students, so that it is ensured students can learn legal knowledge whenever and wherever possible. Benefited by continuous development of mobile network technology, students prefer to learn knowledge, share experiences and make comments in a mobile environment. With the Internet technologies and platforms, students can share good courses or information in a timely manner. Based on the concept of MOOCs, the mobile client not only includes curriculum information, relevant instruction videos, but also increases the interactive learning and discussion worlds. Rich information on these platforms helps students better learn legal knowledge and get more familiar with the significance of learning laws, thus greatly improving the teaching quality and effect.

\section{Conclusion}

- MOOC teaching in China evolves at a relatively fast speed. Its major advantages are reflected in the following ways: a lot of learners engage in learning, no spacetime limit is imposed upon students in learning process, there is a wide coverage of curriculum, complete teaching program and integral teaching materials. The user group has different preferences for the curriculum. In general, they have a great demand for vocational skills and undergraduate education.

- It is found by the investigation that the open questions in the legal education of students in China are that the teaching and evaluation methods are relatively simple, there is lack of the pedagogical practice, the teachers' pedagogies remain to be improved, and the students' enthusiasm for law education is not high.

- Based on the B/S architecture and the concept of MOOC, the design of the law education platform for students in universities can be improved with curriculum re- 
finement and mobile clients developed intensively, thereby contributing much to improving the quality of law education for students in universities.

\section{$7 \quad$ References}

[1] Brawner, K. W., Gonzalez, A. J. (2015). Modelling a learner"s affective state in real time to improve intelligent tutoring effectiveness. Theoretical Issues in Ergonomics Science, 128. https://doi.org/10.1080/1463922x.2015.1111463

[2] Hwang, S. H., Cho, M. H., Kang, S. K., Lee, T. W., Park, H. H., Rho, B. S. (2007). Twodimensional optical interconnection based on two-layered optical printed circuit board. IEEE Photonics Technology Letters, 19(6): 411-413. https://doi.org/10.1109/lpt.2007.892 $\underline{888}$

[3] Li, Z., Han, Z. (2008). An isochrone data base and a rapid model for stellar population synthesis. Monthly Notices of the Royal Astronomical Society, 387(1): 105-114. https://doi. org/10.1111/j.1365-2966.2008.12793.x

[4] Tran, T., Teh, K. (2015). Energy and spectral efficiency of leakage-based precoding for large-scale mu-mimo systems. IEEE Communications Letters, 19(11): 1-1. https://doi.org/ $\underline{10.1109 / \text { lcomm.2015.2475757 }}$

[5] Wang, Y. M., Chen, B. S., Li, Y., Zhang, S. H. (2010). Research on dynamic design method based on measuring information for printing press. Advanced Materials Research, 174: 290-294. https://doi.org/10.4028/www.scientific.net/amr.174.290

[6] Koprü, R., Kuntman, H., Yarman, B. S. (2014). On numerical design technique of wideband microwave amplifiers based on gan small-signal device model. Analog Integrated Circuits and Signal Processing, 81(1): 71-87. https://doi.org/10.1007/s10470-014-0355-4

[7] Ross, L. A., Crabtree, B. L., Theilman, G. D., Ross, B. S., Cleary, J. D., Byrd, H. J. (2007). Implementation and refinement of a problem-based learning model: a ten-year experience. American Journal of Pharmaceutical Education, 71(1): 17. https://doi.org/10.5688/aj710 $\underline{117}$

[8] Tam, V., Moros, T., Webb, S., Allinson, J., Lee, R., Bilimoria, E. (1996). Application of alarp to the design of the bp andrew platform against smoke and gas ingress and gas explosion. Journal of Loss Prevention in the Process Industries, 9(5): 317-322. https://doi.org /10.1016/0950-4230(96)00008-3

[9] Zhang, N. (2018). Development and application of an English network teaching system based on MOOC, International Journal of Emerging Technologies in Learning, 13(7): 149160. https://doi.org/10.3991/ijet.v13i07.8802

[10] Yu, J., Lu, D., Hao, G. (2016). Design and analysis of a compliant parallel pan-tilt platform. Meccanica, 51(7): 1559-1570. https://doi.org/10.1007/s11012-015-0116-1

[11] Kotowicz, J., Bartela, U. (2011). The influence of the legal and economical environment and the profile of activities on the optimal design features of a natural-gas-fired combined heat and power plant. Energy, 36(1): 328-338. https://doi.org/10.1016/j.energy.2010.10. $\underline{035}$

[12] Maguire, R. (2009). Legal issues in the design and implementation of environmental offset and environmental trading frameworks. Molecular Microbiology, 10(1): 45-56. http://dx.doi.org/10.1111/j.1365-2958.1993.tb00902.x 


\section{Authors}

Xue Yang has graduated from Yanshan University with the major of law. She has lectured in college and published five papers and participated in the compilation of a professional textbook for college. She hosted and participated in five provincial and school-level scientific research topics.

Zhen Song, female, Party members, lawyers, instructors, graduated from Shijiazhuang School of Economics, research direction:economic law. I have written a high vocational college "18" planning materials. Nine professional papers have been published, one of which is a national core journal and five are provincial journals.

Article submitted 2019-04-29. Resubmitted 2019-07-02. Final acceptance 2019-07-02. Final version published as submitted by the authors. 